\title{
A STUDY OF BANKRUPTCY PREDICTION \\ IN SRI LANKA
}

By

KASTHURI ARACHCHIGE KAMAL GNANAWEERA

Student RegistrationtH: 5266FM2009029

A research submitted to the

University of Sri Jayewardenepura in partial fulfillment of the requirements for the

Degree of Master of Business Administration (Finance) 


\section{DECLARATION}

"The work described in this research was carried out by me under supervision of Dr. P.D Nimal, Senior lecturer, and report on this has not been submitted in whole or in part to any university or any other institution for another degree or diploma."

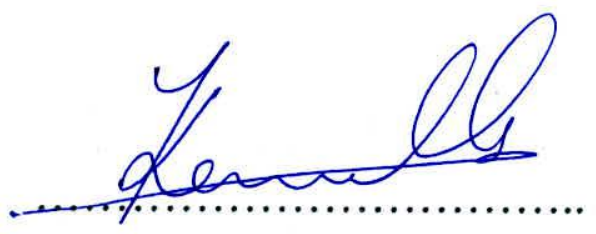

\section{Mr. K.A.K Gnanaweera}

\section{Reg: 5266FM2009029}

Date: ...14!.12/2011 


\section{CHAPTER 1}

\section{INTRODUCTION}

\subsection{Background of the Study}

Almost all stake holders, Managers, stockholders, lenders and employees are concerned about their firm's financial status. If the financial status of the firm is not satisfactory the job security of managers and employees is not guaranteed, and stockholders' equity and lenders' privileges are at stake.The state, as a regulator in a market, has concerns about the occurrence of financial distress of corporations (Xu and Zhang, 2004). This creates a demand among executives, employees and stockholders for information on the financial status of the firm, to be sure of its future. Further,managementmakes frequent inquiries and regular efforts to react to a continuous demand on how financial distress is predicted.

The recent credit crunch in the US share market which was initially triggered by the sub-prime issue, resulted in the collapse of a large number of financialinstitutesviz., banks, corporations and stock markets. Most of Europe still faces financial difficulties and economic hardships, which do not seem to have feasible solutions. Similarly in 2006, the Saudi Arabian Stock market collapsed losing over 1300 points in the price index, $65 \%$ of it at the top level. This phenomenon had an adverse outcome on a large portion of the population and several deaths and cases of serious illnesses are recorded as a result (Al-Rawi, 2008). This was the first time such an event had occurred in the 


\section{SUPERVISOR APPROVAL}

I approve the Research Paper titled "Study of Bankruptcy Prediction in Sri Lanka" by K.A.K. GNANAWEERA; Student Registration\#: 5266FM2009029, for the submission to The Faculty of Management \& Commerce, University of Sri Jayewardenepura, Sri Lanka in partial fulfillment of the requirement of the Master of Business Administration in Finance Degree.

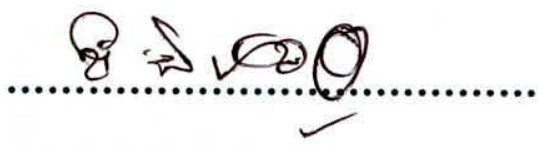

Dr. P D Nimal

Coordinator - MBA Program

Senior Lecturer

Department of Finance

University of Sri Jayewardenepura

Sri Lanka

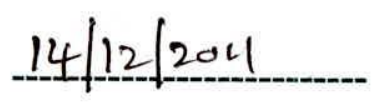

Date 


\section{ACKNOWLEDGEMNETS}

We all need someone to open doors for us. Therefore, I,enthusiastically, express thanking to my supervisor, our MBA program Course Coordinator and senior lecturer Dr. P D Nimal.

My gratitude goes to my all lecturers throughout the period of MBA program and special gratitude goes to Professor K.D. Gunawardana for assisting me on my research proposal. Further, I highly appreciate other scholars, academics, journalists, business researches, and corporate people whose works forms the foundation of this essay. It is their ideas, their research, and their experience that is reflected within these pages.

Sincerely, I appreciation following persons who dedicated their time and energy for my work:

- To my friends who gave assistance by providing materials, support, \& advise

- To University non-academic staff

- To staff in the Colombo Stock Exchange

- To Staff in Registrar of Companies

- Especially to my parents, the support which never match with any, for their immense contribution behind thisstudy and for the MBA program

I look forward to an exciting and challenging future with success! 


\begin{abstract}
The most pervasive reason for a firm to be gone in distress and possible failure is some type of managerial incompetence. Many external stakeholders are not involved in the day-to-day business procedures of a company but need to know the financial health of a company they have interests in. Financial reporting has become an important module of communication between a corporates and stakeholders. The quest of finding a simple and accurate bankruptcy prediction system or model is in high demand by many stakeholders to detect the present and future health of a company. Many researchers depend on different kind of models but Altman's Z-score model is being used significantly in many organizations, worldwide, because of its level of accuracy and simplicity of calculation using freely available financial data. The purpose of the research is to determine the accuracy and predictability of Altman's Z-score model(s): Z" and Z"', in Sri Lankan context.
\end{abstract}

This research examines 33 de-listed companies and good companies (listed); 2 to 3 year periods prior de-listing by using their financial information to calculate Z-score value. Further, this study examines Z-score values for de-listed \& bankrupted companies with good companies and de-listed \& non-bankrupted companies with good companies 2 and 3 year periods prior de-listing to identify bankruptcy prediction accuracy of Altman's Zscore model(s).

This study identifies that the Z" model achieved $92 \%$ prediction accuracy when it is applied to de-listed and bankrupted companies 3 years prior to de-list and $100 \%$ 
prediction accuracy when it is applied to de-listed and bankrupted companies 2 years prior to de-list. Conversely the Z"1 model achieved $83 \%$ prediction accuracy when it is applied to de-listed and bankrupted companies 3 years prior to de-list and 100\% prediction accuracy when it is applied to de-listed and bankrupted companies 2 years prior to de-list.but the Z" model predicted $13 \%$ of de-listed and non-bankrupted companies 3 years prior de-listing which may lead to insolvency and $19 \%$ of de-listed and non-bankrupted companies 2 years prior de-listing which may lead to insolvency. Further the Z"1 model predicted 13\% of de-listed and non-bankrupted companies 3 years prior de-listing which may lead to insolvency and $13 \%$ of de-listed and non-bankrupted companies 2 years prior de-listing which may lead to insolvency. Therefore according to evidence suggests the prediction accuracy of Z"1 modelslightly betterthan the Z" model.

The results obtained in this study are subject to information restraints as availability of relevant information for de-listed companies was limited. Hence further research is needed to evaluate the soundness of the Z-score model(s) for bankruptcy prediction in Sri Lankan Context. 


\section{CONTENT OF TABLES \& FIGURES}

\section{CONTENT OF TABLES}

Table 2.1: Market statistics from 1999 to 2003

Table 2.2: Market statistics from 2004 to 2010

Table 3.1: Number of de-listed Companies, 2000 to 2010

Table 4.1: Comparison I on Z-score Values for

De-listed companies and Listed companies

Table 4.2: Comparison II on Z-score Values for

De-listed companies and Listed companies

Table 4.3: Comparison III on Z-score Values for

De-listed companies and Listed companies

Table 4.4: Comparison IV on Z-score Values for

De-listed companies and Listed companies

Table 4.5: Comparison V on Z-score Values for

De-listed companies and Listed companies

Table 4.6: 2 and 3 year period prior to de-listing,

Z-score results for de-listed and listed companies

Table 4.7: Analysis of bankrupted companies

According to Altman's Z-score

Table 4.8: 3 Years Prior to de-listing Z-Score results in percentage

Table 4.9: 2 Years Prior to de-listing $Z$-Score results in percentage

Table 4.10: Analysis of de-listed \& Non-bankrupted Companies

According to Altman's Z-score models

Table 4.11: 3 Years Prior to de-listing Z-Score results in percentage

Table 4.12: 2 Years Prior to de-listing Z-Score results in percentage 
Table 4.13: 3 Years Prior to de-listing Z-Score results in percentage

\section{CONTENT OF FIGURES}

Figure 2.1: Financial Category for Manufacturing Companies

Figure 2.2: Financial Category for Private companies

Figure 2.2: Financial Category for Emerging Markets

Figure 3.1 Conceptual Frame Work

Figure 3.2: Structure of the companies selected for the sample

Figure 4.1: Z" scores Comparison of De-listed \& Bankrupted

Companies (3 years prior to de-listing) \& Good Companies87

Figure 4.2: Z" scores Comparison of De-listed \& Bankrupted

$$
\text { Companies (2 years prior to de-listing) \& Good Companies }
$$

Figure 4.3: Z"1 scores Comparison of De-listed \& Bankrupted

$$
\text { Companies (3years prior to de-listing) \& Good Companies }
$$

Figure 4.4: $Z^{\prime 1}$ scores Comparison of De-listed \& Bankrupted

$$
\text { Companies (2years prior to de-listing) \& Good Companies }
$$

Figure 4.5: Z"-scores Comparison of De-listed \& Non-Bankrupted

$$
\text { Companies (3 years prior to de-listing) }
$$


Figure 4.6: Z"-scores Comparison of De-listed \& Non-Bankrupted

$$
\text { Companies (2years prior to de-listing) }
$$

\& Good Companies

Figure 4.7: Z"'-scores Comparison of De-listed \& Non-Bankrupted

$$
\text { Companies ( } 3 \text { years prior to de-listing) }
$$

\& Good Companies

Figure 4.8: $Z$ "' -scores Comparison of De-listed \& Non-Bankrupted

$$
\text { Companies (2 years prior to de-listing) }
$$

\& Good Companies 


\section{ABBREVIATIONS}

AMW

ANN

ASPI

BE

CFA

CO.

CSE

DEV.

EBIT

FD

GP

LTD

M \& A

MDA

MN.

MVE

NDB

NO.

PLC

PROP.

PVT.

ROC

SLT

UK

USA
Associated Motorways

Artificial Neural Networks

All Share Price Index

Book value of Equity

Charted Financial Analyst

Company

Colombo Stock Exchange

Development

Earnings Before Interest \& Tax

Financial Distress

Gross Profit

Limited

Mergers \& Acquisition

Multiple Discriminant Analysis

Million

Market Value Equity

National Development Bank

Number

Public Limited Company

Property

Private

Registrar of Companies

Sri Lanka Telecom

United Kingdom

United States of America 


\section{CONTENT}

DECLARATION

i

SUPERVISOR APPROVAL

ACKNOWLEDGEMENT

ABSTRACT

CONTENT OF TABLES \& FIGURES

ABBREVIATIONS

\section{CHAPTER 1}

\section{INTRODUCTION}

1.1 Background of the Study

1.2 Problem statement

1.3 Problem justification

1.4 Objectives of the study

1.5 Methodology

1.6 Scope of the Study

1.7 Limitations of the research

1.8 Significance of the study

1.9 Organization of the report 


\section{CHAPTER 2}

\section{LITERATURE REVIEW}

2.1 Chapter Introduction

2.2 De-listed Companies in Sri Lanka

2.3 Bankruptcy

2.4 Reasons for corporate failures

2.5 Models used in Bankruptcy Prediction

2.6 Empirical Evidence on Bankruptcy Prediction Models

2.7 Chapter summary

\section{CHAPTER 3}

\section{RESEARCH METHODOLOGY}

3.1 Introduction to the Chapter

3.2 Research approach

3.3 Conceptual Frame work 


\section{CHAPTER 4}

\section{ANALYSIS AND FINDINGS}

4.1 Introduction to the chapter

4.2 Comparisonon Altman's Z-score results for

De-listed and Listed companies

4.3 Outcome for the De-listed and Listed companies according to Altman's Z-score model(s)

4.4 Analysis on evaluation of Altman's Z-score model for the de-listed and bankrupted companies in Sri Lanka

4.5 Analysis on evaluation of Altman's Z-score model for the De-listed \& Non-bankrupted companies in Sri Lanka

4.6Z-score Comparison of De-listed \& Bankrupted companies and De-listed \& Non-Bankrupted companies 


\section{CHAPTER 5}

\section{FINDINGS AND DISCUSSION}

5.1 Introduction to the chapter summary

5.2 Findings for the bankruptcy prediction accuracy

of Altman's Z-score models (Z" \& Z"1)

5.3 Discussion on Prediction Accuracy of Z-score models

5.4 Possible Managerial Implications

\section{CHAPTER 6}

\section{SUMMARY \& CONCLUSION}

Summary and Conclusion

Reference

Appendixes I: The delisted companies of 2000 to 2010 